\title{
THE RELATIONSHIP BETWEEN NATIONAL INTELLECTUAL CAPITAL AND CORRUPTION: A CROSS-NATIONAL STUDY
}

\author{
Agata Stachowicz-Stanusch \\ Silesian University of Technology, Roosevelt Street 42, 41-800 Zabrze, Poland \\ E-mail: agata.stachowicz@polsl.pl
}

Received 11 October 2011; accepted 15 February 2012

\begin{abstract}
The main objective of this paper is to examine the relationship between the National Intellectual Capital and the Corruption Perception Index. The analysis of the relationship between the NIC and the CPI was conducted for 16 countries: Austria, Belgium, the Czech Republic, Finland, France, Germany, Greece, Hungary, Ireland, Italy, Netherlands, Poland, Portugal, Spain, Sweden and the United Kingdom and was based on NIC data extracted from two sources (Carol Yeh-Yun Lin and Leif Edvinsson (2010), and the generational approach to the National Intellectual Capital measurement presented in the Report on the Intellectual Capital of Poland).

Determination of the strength of the correlation between NIC and CPI represents the first step in evaluating intellectual capital as the factor which may reduce the scale of corruption. Evidence of a strong relationship between NIC and CPI confirms the author's hypothesis that a strong relationship exists, at the same time proving that further studies must be carried out to determine the direction of this relationship. Based on the results of such research (providing that NIC is confirmed to have an effect on CPI), it will then be possible to recommend new methods of preventing corruption through the development of NIC.
\end{abstract}

Keywords: National Intellectual Capital, Corruption Perception Index, building national wealth, corruption.

Reference to this paper should be made as follows: Stachowicz-Stanusch, A. 2013. The relationship between National Intellectual Capital and corruption; a cross national study, Journal of Business Economics and Management 14(1): 114-139.

JEL Classification: M190.

\section{Introduction}

Corruption, which is often defined as the misuse of public office for private gains, is a new challenge for managerial sciences during last decade. Although corruption is a widespread phenomenon that has existed from the earliest times and has been a significant phenomenon in public institutions for centuries, during the last years it has become one of the most important managerial issues. Both governments and private firms face similar problems related to corruption. Empirical research shows that the presence of high corruption significantly hinders the inflow of foreign direct invest- 
ment (FDI) to host countries (Zhao et al. 2003) and negatively affects economic success (Seleim, Bontis 2009). Dealing with corruption has become an important issue in building national wealth. In the same period of time another complex phenomenon named intellectual capital has attracted the interest of the managerial sciences. The early phase of intellectual capital research in the eighties and nineties concentrated mainly on the microeconomic context, but at the beginning of the 2000s macro-level research on intellectual capital started to emerge. It is widely believe that investing in National Intellectual Capital creates opportunity to a country's development and the wealth of its citizens. Hence, the main objective of this paper is to examine the relationship between National Intellectual Capital and the Corruption Perception Index.

\section{Corruption impact on the country's development and citizens' wealth}

During the past decade corruption has ranked highly on the agenda of multinational development agencies, private firms, and policy-makers; it has become one of the most prominent managerial issues at the individual (Trevino 1986; Aquino, Reed 2002; Marcus, Schuler 2004; Eisenberg 2000; Reynolds 2006; Banaji et al. 2003), organizational (Ashforth et al. 2008; Baucus, Near 1991; Brief et al. 2001; Pinto et al. 2008), national and international (Callahan 2004; Punch 2003) level.

The recent increase in interest in corruption is related to a couple of factors, the most important being that corruption has become more prevalent in the global economy (Coupet 2003; Seleim, Bontis 2009). The recent corruption scandals made us realize that many corporations operating in the international marketplace have no clear notion of their responsibilities to the individuals and whole nations. Unethical corruptive behavior of corporations operating multinationally can have a devastating impact on individuals and communities, and it has become one of the most important managerial issues at the individual, organizational, and national levels. Corruption practices in international business are widespread and growing (Seleim, Bontis 2009), and research investigated corruption and its impact on a country's political, economic, and cultural infrastructure has focused a great deal of attention. Corruption weakens markets, reduces competitiveness, diverts investments, and increases economic uncertainty (Shkolnikov, Wilson 2005).

Empirical research shows that high levels of corruption mean reduced investment, a lack of credible guarantees for property and contract rights, and poor institutionalization of the government (Moily 2009). To a large extent most of researchers have provided support for a negative effect of corruption on investment and economic growth, showing that corruption negates the standard of living (Seleim, Bontis 2009). Corruption is closely related to GDP per capita and to human capital. These correlations are consistent with the economic and human capital theories of institutional development (Moily 2009). Countries with high levels of corruption invest very little in human capital and in particular, the investment in education is only minimum. Robert Cooter's study (2000) shows that a society with high levels of corruption has low levels of social interaction and is characterized by the weaknesses of the rule of law. The study by Easterly and Levine (1997) establishes that a society with large incidence of corruption is characterized by deep ethnic divisions and conflicts. A high level of corruption and the lack of 
trust in the government can negatively affect the level of trust and social capital among citizens (Svendsen 2003). In general, the corrupt countries with the lowest levels of trust also have smaller Gross Domestic Product per capita levels, while those with less corruption are characterized by more trust and higher Gross Domestic Product per capita. The empirical findings suggest that the increased levels of corruption reduce a country's standard of living (Coupet 2003). Gupta et al. (2001) show that countries with high levels of corruption are associated with inefficient government services and a low quality of public health care. Despite the fact that our knowledge about corruption prevention is increasing at remarkable speed and there are extensive efforts within governmental, non-governmental, and international organizations to establish specific guidelines in order to prevent corruptive practices of international business (Getz, Volkema 2001), fighting corruption is still very difficult. Corruption as a multi-faceted social phenomenon rooted in many aspects of societies can never be completely eliminated. However, countries cannot ignore the problem simply because of the theoretical argument that has always existed (Shkolnikov, Wilson 2005). Discovering the best ways for corruption prevention and solutions to bring corruption under control have become an important issue in building national wealth and the state's institutional capacity (World Bank 1997).

During the last years many researchers have made a great effort not only to identify the consequences of corruption but also to identify the factors which may lead to its reduction. It has been suggested that the overall size of the government budget relative to GDP may be positively correlated with levels of corruption (La Palombara 1994). Elliot (1997) reports for a sample of eighty-three countries that the size of the government budget relative to GDP decreases with levels of corruption. Broadman and Recanatini (1999) show a sample of transition economies in Europe and Central Asia in which higher barriers to market entry lead to higher corruption. Gerring and Thacker (2005) report that there is a positive correlation between the regulatory quality and the absence of corruption. Ades and Di Tella $(1997,1999)$ conclude that policy intervention causes corruption. Goel and Nelson (2005) observe a positive association between corruption and government regulation of and involvement in the financial sector. Henderson (1999) argues that corruption is negatively correlated with different indicators of economic freedom. This result is largely supported by Goldsmith (1999), Paldam (2002), Lambsdorff (2007). In societies where the level of generalized trust and civic engagement is high, people are more willing to deal with individuals who are different from them, which encourages co-operation with those who are outside one's narrow social network (Harris 2007). Trusting societies are more likely to have efficient governments, higher level of economic development, and thus, less corruption (Bjornskov 2004). However, a number of scholars have also acknowledged that social capital does not always produce positive externalities (Fukuyama 1995, 1999; Putnam 2000; Harris 2007).

Nevertheless, delegating less discretionary power to public officials (Bjornskov 2003) and decentralizing fiscal authority (Bjornskov 2003) have also been found to lead to lower corruption. The extent to which the level of public sector salaries is linked to the amount of corruption was examined and it was argued that low salaries force public servants to supplement their incomes (Rijckeghem, Weder 2001). Finally, Alt and 
Lassen (2002) show that political competition leads to less corruption in a sample of 45 American states (Lambsdorff 2007). Herzfeld and Weiss (2003) exhibit a strong negative correlation between law and order and corruption. A correlation between them and the independence of the judicial system is proposed in Ades and Di Tella (1995). Also Sung (2002) reports this result, albeit missing to control the income per capita. Corruption diminishes with embracing a composite index (Lambsdorff 2007). Many of those elements may be shaped in an aware and deliberate way through the appropriate supportive actions in the long run. Those elements may be also a part of a wider idea of National Intellectual Capital. The intellectual capital of a nation which includes the hidden values of individuals, enterprises, institutions, communities and regions, is the current and potential source for wealth creation (Bontis 2004). Since knowledge has turned out to be the key source of wealth at an organizational as well as the national level, the countries with knowledge-intensive activities will be the winners in terms of future wealth creation (Lin, C. Y. Y., Lin, T. Y. 2008). It is widely believe that investing in National Intellectual Capital creates opportunity to a country's development and the wealth of its citizens.

Ashour (2006) classified the underpinning factors of corruption into the political infrastructure of a state, economic structure, institutional infrastructure, and sociocultural infrastructure, therefore, corruption is an outcome of a country's political and legal aspects, economic and structural policies, the role of institutions, human development, and globalization (Seleim, Bontis 2009). Hence, the main objective of this paper is to examine the relationship between the National Intellectual Capital and the Corruption Perception Index. The previously mentioned research results suggest that despite conducting studies on the influence of various elements that constitute the National Intellectual Capital, there is still a lack of research on the relationship between the intellectual capital of particular countries and their corruption level.

\section{National Intellectual Capital - the definition, models and measurement methods}

Over the past few decades intangible assets, such as knowledge, patents, and innovation (Lin, C. Y. Y., Lin, T. Y. 2008), have been discovered as fundamental sources of wealth and development. The concept of intellectual capital was expounded on by a management guru, Drucker (1993) in his description of a post-capitalist society. Drucker (1993) highlights the importance and the arrival of a society that is dominated by knowledge resources and the competitive landscape of intellectual capital allocation. Since the intellectual capital of a nation which includes the hidden values of individuals, enterprises, institutions, communities and regions (Bontis 2005) is the current and potential source for wealth creation, those intangible assets represent the fount of nation's competences and capabilities that are deemed essential for economic growth, human development and the quality of life (Malhotra 2003). As a result, the countries that are rich in these intangible assets fare better in terms of national wealth than those whose assets are limited to land, tools and labor (Malhotra 2003; World Bank 1998). Intellectual capital is very complex phenomenon that is difficult to measure and identify. The early phase 
of intellectual capital research in the 80 s and 90 s concentrated mainly on the microeconomic context, but recently regional and national perspectives have also attracted interest within the intellectual capital community (Ståhle 2008). Over the last decade various models and classifications have been presented with many measurement and reporting applications. The National Intellectual Capital (NIC) refers to the concept "that applies the principles of intellectual capital measurement and management on a macroeconomic level, in such a way that it helps to give direction to future economic development" (Ståhle 2008). Macro-level research on intellectual capital started to emerge at the beginning of the 2000s. The managers of corporations and government officials who are responsible for promoting national economic development are trying to find reliable ways to measure intellectual capital and to gain a clearer understanding of how these relate to future performance (Malhotra 2000). There have been many initiatives to measure National Intellectual Capital. Rembe (1999) examined the components of national attraction from the viewpoint of foreign investments in Sweden and proposed a strategic plan for the future development of Sweden's human capital, market capital, process capital and renewal capital. Several another researchers carried out similar initiatives to assess the intellectual capital of Israel (Pasher 1999), the Arab region (Bontis 2004), Sweden (Spring Project 2002), Taiwan (Lin, C. Y. Y., Lin, T. Y. 2008; Lin, Edwinnson 2010) and Poland (The Board of Strategic Advisers to the Prime Minister of Poland 2008). The model introduced by Edvinsson and Malone (the E\&M model) has been mostly used to measure National Intellectual Capital, and no specific macro models have been developed. The common view among academics is that there is no need for specific National Intellectual Capital model, since the intellectual capital concept is relatively transferable from the micro to the macro level (Andriessen, Stam 2004; World Bank 2002; Lin, Edvinsson 2010). In addition, comparative analyses have also been conducted by international institutions, such as the Human Development Index (UNPAN 2003), the Knowledge Assessment Methodology (KAM) and the Knowledge Economy Index (KAM 2007), the Innovation Scoreboard (EIS 2006, 2007; see also: EU 2004, 2005, 2006a, 2006b), measurement recommendations (OECD 2006).

Scientists from different disciplines have proposed different models to evaluate the National Intellectual Capital. Since this field of study is still developing, a consensus regarding the set of determinants that should be employed has yet to be reached (Lin, Edvinsson 2010). Building on the relevant research from the past, Lin and Edvinsson (2010) propose a framework and a model of intellectual capital measurement and then test this model by using the widely accepted International Institute for Management Development (IMD) databases, which contain both quantitative and qualitative indicators. The research on the 14 years' data, spanning from 1995 to 2008, indicates the pattern and progression of National Intellectual Capital in 40 countries. 29 variables were selected - seven for each of the following: human capital, market capital, process capital, and renewal capital; and a single variable (GDP per capita adjusted by purchasing power parity) representing the financial capital. The first type of National Intellectual Capital, the human capital, was defined as the competencies of individuals in realizing national goals (Bontis 2004). According to OECD (2000), human capital consists of knowl- 
edge about facts, laws, and principles in addition to knowledge relating to teamwork, and other specialized and communication skills. Education is the foundation of human capital. The second type of national capital, the market capital, is similar to external relational networking and social capital in a micro-setting in that it represents a country's capabilities and successes in providing an attractive and competitive incentive in order to meet the needs of its international clients, while also sharing knowledge with the rest of world (Bontis 2004). The third type of national capital, the process capital, comprises the non-human sources of knowledge in a nation like a country's infrastructure, these sources facilitate the creation, accessibility, and dissemination of information (Lin, Edvinsson 2010). The fourth type of national capital, the renewal capital, is defined as a nation's future intellectual wealth and the capability for innovation that sustains a nation's competitive advantage (Lin, Edvinsson 2010). The other approach to reporting and measuring National Intellectual Capital was presented in The Report on the Intellectual Capital of Poland elaborated by Board of Strategic Advisers - an advisory and consultative body to the Prime Minister of Poland in 2008 (The Board of Strategic Advisers to the Prime Minister of Poland 2008). The underlying assumption of this approach was the measurement of intellectual capital in a generational perspective, which would enable the assessment of the developmental potential of a nation related to each individual generation. The conceptual model of the intellectual capital of individual generational groups was designed in compliance with the general framework of the intellectual capital concept established in the professional literature (The Board of Strategic Advisers to the Prime Minister of Poland 2008). The intellectual capital of a country is the total of intangible assets of people, enterprises, communities, regions, and institutions, which, properly utilized, may become the source of the present and future well-being of the country; it consists of the following components: human capital, social capital, structural capital, relational capital. Therefore, certain subcategories of intellectual capital were distinguished and afterwards separate measurement models were developed for each of them, which were then used as variables, enabling construction of the measurement model of intellectual capital of a given generation (The Board of Strategic Advisers to the Prime Minister of Poland 2008).

Measuring and describing the National Intellectual Capital in a generational perspective is an innovative approach. In other countries' reports which have been produced so far the age groups which do not participate in the labor market have been omitted. The Polish approach, recognizing the importance of inter-generational harmony and solidarity, was acknowledged by international experts (The Board of Strategic Advisers to the Prime Minister of Poland 2008). By applying this approach it was possible to create generation-based indexes or ratings of intellectual capital for a particular country (namely, the intellectual capital of children and pupils, students, adults and senior citizens) and of its individual components. Each such index was generated on the basis of the statistical analysis of several up to several dozen indicators. The measurement model used in the Report on Intellectual Capital of Poland (The Board of Strategic Advisers to Prime Minister of Poland 2008) includes 117 indicators. 


\section{Methodology}

The literature on the subject presents many models (ways) for measuring the National Intellectual Capital (NIC), which estimate the value of intellectual capital for a particular country taking into account various elements (human capital, social capital, structural capital, relational capital), types of data (data with an absolute value, such as "patents per capita"; and data with a qualitative rating based on a scale of 1 to 10 , such as "the image of a country") which are based on different number of indicators. Hence, the analysis of dependence between the National Intellectual Capital (NIC) and the Corruption Perception Index (CPI) was conducted, which was based on NIC data extracted from two sources. The aim of such analysis was to increase the reliability and the credibility of research.

The data used for NIC and CPI relationship analysis were taken from the research results of Carol Yeh-Yun Lin and Leif Edvinsson (2010) and the data gained from the generational approach to the National Intellectual Capital measurement presented in the Report on the Intellectual Capital of Poland (The Board of Strategic Advisers to the Prime Minister of Poland 2008).

\section{Research variables}

The perceived level of corruption is a dependent variable. The present study used the published data of CPI (Transparency International 2008). Much criticism has been addressed against the CPI, in the terms of inaccuracy, inconsistency and real impossibility to assess what a particular given degree of corruption means for a country. However, the CPI has revealed as a powerful tool, accepted worldwide (Urra 2007). Among the policy makers, the CPI is the most widely disseminated index (Svensson 2005). The value of NIC based on NICI40 by Lin and Edvinsson (2010), which consists of human, market, process, renewal and financial capital, estimated in a generational approach within which the National Intellectual Capital is recognized as children's intellectual capital (IC), students' IC, adults' IC and seniors' IC, is analyzed in the research process as an independent variable.

GDP per capita represents the controlling variables in this study.

\section{Research hypotheses}

In the research process the main hypothesis was formulated:

H1: There is a correlation between National Intellectual Capital (NIC) and the Corruption Perception Index (CPI).

Because in the research process two different methods for National Intellectual Capital calculation were used, different detailed hypotheses for particular methods were created. Hence, for the National Intellectual Capital method (NICI40) by Lin and Edvinsson (2010), those detailed hypotheses are as follows:

H2: There is a correlation between the human capital level of a particular country, and the corruption level of this country. 
H3: There is a correlation between the market capital level of a particular country, and the corruption level of this country.

H4: There is a correlation between the process capital level of a particular and the corruption level of this country.

H5: There is a correlation between the renewal capital level of a particular country and the corruption level of this country.

H6: There is a correlation between the financial capital level of a particular country and the corruption level of this country.

The controlling hypothesis:

H7: There is a correlation among GDP per capita along with NIC and CPI.

Similarly, for the generational approach to the NIC measurement there were formulated the following detailed hypotheses:

H8: There is a correlation between the students' intellectual capital (IC) level of a particular country and the corruption level in this country.

H9: There is a correlation between the adults' IC level of a particular country, and the corruption level in this country.

H10: There is a correlation between the seniors' IC level of a particular country, and the corruption level in this country.

Adults' intellectual capital within the generational method consists of four elements such as human capital (HC), social capital (SC), structural capital (STRC) and relational capital (RC). Hence, the following detailed hypotheses were formulated:

H11: There is a correlation between the adults' $\mathrm{HC}$ level of a particular country, and the corruption level.

H12: There is a correlation between the adults' SC level of a particular country, and the corruption level.

H13: There is a correlation between the adults' STRC level of a particular country, and the corruption level.

H14: There is a correlation between the adults' RC level of a particular country is, and the corruption level.

In the generational approach the hypotheses for the active generational groups (or potentially professionally active ones) were verified. Hence the hypotheses capturing children and pupils were excluded, although the children and pupils' intellectual capital illustrates the development potential of a particular country.

The hypothesis for the controlling variable:

H15: There is a relationship among the GDP per capita along with the NIC (or the adults' IC) and the CPI level. 


\section{Research sample}

The analysis of the relationship between the NIC and the CPI was conducted for 16 countries. The sample size was dependent on the existence of the results for a particular country for both of the NIC measurement methods. The research was conducted for the following countries: Austria, Belgium, the Czech Republic, Finland, France, Germany, Greece, Hungary, Ireland, Italy, Netherlands, Poland, Portugal, Spain, Sweden and the United Kingdom.

\section{Data sources}

Data were obtained from well-established sources in order to increase validity and reliability. As for the dependent variable (corruption), the present study used the CPI data (ranging from corruption free $=10$ to totally corrupt $=0$ ) published in 2008 (Transparency International 2008). Lambsdorff (1999; see Harris 2007) indicated that the perceived level of corruption is generally a good indicator of the real level of corruption. The CPI was documented in previous research (Lancaster, Montinola 1997). NIC values within the NICI40 method were extracted from the Overall NICI40 - the National Intellectual Capital score and ranking based on the country sequence (Lin, Edvinsson 2010). NIC values within the generational method were estimated and normalized up to $100 \%$ NIC value for all countries data presented in the Report on the Intellectual Capital of Poland (The Board of Strategic Advisers to the Prime Minister of Poland 2008). The values of the intellectual capital for particular generation groups and the average values of NIC are presented in Table 1. The National Intellectual Capital (NIC) values for the analyzed countries within the both measurement methods as well as for the level of Corruption Perception Index (CPI) and GDP per capita in individual coutries are presented in Table 2.

Table 1. Values of intellectual capital for particular generational groups

\begin{tabular}{lccccc}
\hline \multicolumn{1}{c}{ Country } & $\begin{array}{c}\text { Children's IC } \\
{[\%]}\end{array}$ & $\begin{array}{c}\text { Students' IC } \\
{[\%]}\end{array}$ & $\begin{array}{c}\text { Adults' IC } \\
{[\%]}\end{array}$ & $\begin{array}{c}\text { Seniors' IC } \\
{[\%]}\end{array}$ & $\begin{array}{c}\text { Average NIC } \\
\text { value [\%] }\end{array}$ \\
\hline Holland & 43 & 51 & 69 & 63 & 56.5 \\
\hline Sweden & 48 & 80 & 84 & 66 & 69.5 \\
\hline Austria & 71 & 46 & 65 & 62 & 61 \\
\hline Finland & 31 & 62 & 70 & 61 & 56 \\
\hline Belgium & 53 & 45 & 53 & 58 & 52.25 \\
\hline Ireland & 63 & 65 & 62 & 59 & 62.25 \\
\hline France & 58 & 59 & 42 & 61 & 55 \\
\hline Germany & 80 & 60 & 46 & 64 & 62.5 \\
\hline United & 42 & 81 & 55 & 49 & 56.75 \\
Kingdom & 45 & 35 & 43 & 51 & 43.5 \\
\hline Italy & & &
\end{tabular}


End of Table 1

\begin{tabular}{lccccc}
\hline Spain & 51 & 29 & 40 & 56 & 44 \\
\hline Greece & 25 & 42 & 24 & 39 & 32.5 \\
\hline Portugal & 27 & 32 & 34 & 57 & 37.5 \\
\hline $\begin{array}{l}\text { Czech } \\
\text { Republic }\end{array}$ & 52 & 44 & 23 & 36 & 38.75 \\
\hline Hungary & 78 & 31 & 46 & 22 & 44.25 \\
\hline Poland & 35 & 34 & 29 & 7 & 26.25 \\
\hline
\end{tabular}

Source: authors' own study based on Report on Intellectual Capital of Poland (Board of Strategic Advisers to Prime Minister of Poland 2008).

Table 2. National Intellectual Capital within two measurement methods and Corruption Perception Index 2008 and GDP per Capita 2008

\begin{tabular}{|c|c|c|c|c|}
\hline Country & NIC by method $1^{1}$ & NIC by method $2^{2}$ & CPI 2008 & GDP per Capita 2008 (USD) \\
\hline Holland & 56.5 & 35.56 & 8.9 & 38600 \\
\hline Sweden & 69.5 & 38.89 & 9.3 & 36900 \\
\hline Austria & 61 & 33.96 & 8.1 & 39000 \\
\hline Finland & 56 & 39.03 & 9 & 35500 \\
\hline Belgium & 52.25 & 32.97 & 7.3 & 36500 \\
\hline Ireland & 62.25 & 33.77 & 7.7 & 45600 \\
\hline France & 55 & 31.24 & 6.9 & 33800 \\
\hline Germany & 62.5 & 33.48 & 7.9 & 34400 \\
\hline $\begin{array}{l}\text { United } \\
\text { Kingdom }\end{array}$ & 56.75 & 32.11 & 7.7 & 35300 \\
\hline Italy & 43.5 & 27.9 & 4.8 & 31000 \\
\hline Spain & 44 & 28.51 & 6.5 & 33700 \\
\hline Greece & 32.5 & 25.87 & 4.7 & 30500 \\
\hline Portugal & 37.5 & 27.28 & 6.1 & 21800 \\
\hline $\begin{array}{l}\text { Czech } \\
\text { Republic }\end{array}$ & 38.75 & 27.15 & 5.2 & 24400 \\
\hline Hungary & 44.25 & 27.99 & 5.1 & 19500 \\
\hline Poland & 26.25 & 23.59 & 4.6 & 16200 \\
\hline
\end{tabular}

Source: authors' own study based on Report on Intellectual Capital of Poland (Board of Strategic Advisers to Prime Minister of Poland 2008; Lin, Edvinsson 2010; Transparency International 2008).

\footnotetext{
${ }^{1}$ Generational approach according to Report on Intellectual Capital of Poland (Board of Strategic Advisers to Prime Minister of Poland 2008).

2 NICI 40 (Lin, Edvinsson 2010).
} 


\section{Research results}

Hypothesis H1: There is a correlation between the National Intellectual Capital (NIC) level and the level of corruption, was verified according to the value of National Intellectual Capital (NIC) extracted from both measurement methods, namely NICI40 and generational method. Before the verification of the H1 hypothesis was initiated on the basis of the values of National Intellectual Capital established on the basis of the NICI40 method, the value of the coefficient of variation $\left(\mathrm{V}^{*}\right)$ of the examined variables had been verified. In statistics it is assumed that the rejection threshold of a given variable is $\mathrm{V}^{*}=0.2$, but due to the low number of analysed countries let us assume that the threshold level of $\mathrm{V}^{*}=0.15$ shall be the critical value and let us further analyse the $I C$ variable $^{3}$. In order to verify whether there is any relationship between the level of National Intellectual Capital and the corruption level of a particular country, a linear economic model has been constructed on the basis of the least squares method.

The following model has been obtained:

$$
y=0.34 x-3.8,
$$

where: $y$ - response (dependent) variable - the level of corruption (CPI); $x$ - responding (independent) variable - the level of intellectual capital - average IC.

The determination coefficient $\mathrm{R}^{2}$ totals 0.9151 , which corresponds to the relationship between the corruption level and the intellectual capital level in a given country. In other words, the econometric model presented above explains almost in 92 per cent the analysed phenomenon. At this stage of the analysis let us apply the F statistics in order to find out whether these results are not accidental. On the significance level $\alpha=0.05$ the critical value $\mathrm{F}^{*}$ for one variable at 14 degrees of freedom $(d f)$ totals 4.6 . In the analysed case this value totals 150.842 and it significantly exceeds the critical value $\mathrm{F}^{*}$.

Let us also verify whether there is any linear correlation between the variables when applying Pearson's $\mathrm{R}$ test. The obtained value was $\mathrm{R}=0.957$, which means that there is almost ideal positive correlation between the analysed phenomena. There is a positive linear relationship between the variables (rather strong).

A similar procedure was applied for the verification of the subsequent hypotheses. The following successive results were presented in Table 3.

In the case of the $\mathrm{H} 2$ hypothesis: There is a correlation between the human capital level for particular country and the corruption level of this country, the determination coefficient $\mathrm{R}^{2}$ totals 0.703 , which means that the presented model describes the analysed phenomenon in 70 per cent. The value of Pearson's R test totals 0.838 , which indicates a strong positive relationship between the variables. Conclusion: there is a statistically significant relationship between the analyzed variables.

In the case of the $\mathrm{H} 3$ hypothesis: There is a correlation between the market capital level for particular country and the corruption level of this country, the determination coefficient $\mathrm{R}^{2}$ totals 0.592 , which means that the presented model describes the analysed

\footnotetext{
${ }^{3}$ The rejection threshold $\left(\mathrm{V}^{*}\right)$ for the coefficient of variation $\mathrm{V}$ is adopted on a conventional basis. It is a generally accepted practice among statisticians to use the rejection threshold of the coefficient of variation $\left(\mathrm{V}^{*}\right)$ in the range between 0.1 and 0.2 .
} 
Table 3. Values of human, market, process, renewal and financial capital for particular countries

\begin{tabular}{lccccc}
\hline \multicolumn{1}{c}{ Country } & $\begin{array}{c}\text { Human } \\
\text { Capital }\end{array}$ & $\begin{array}{c}\text { Market } \\
\text { Capital }\end{array}$ & $\begin{array}{c}\text { Process } \\
\text { Capital }\end{array}$ & $\begin{array}{c}\text { Renewal } \\
\text { Capital }\end{array}$ & $\begin{array}{c}\text { Financial } \\
\text { Capital }\end{array}$ \\
\hline Holland & 6.89 & 6.95 & 6.79 & 5.21 & 9.73 \\
\hline Sweden & 7.98 & 6.31 & 7.78 & 7.78 & 9.63 \\
\hline Austria & 6.89 & 6.25 & 6.52 & 4.6 & 9.7 \\
\hline Finland & 7.79 & 6.61 & 7.71 & 7.36 & 9.56 \\
\hline Belgium & 7.01 & 5.86 & 5.79 & 4.66 & 9.64 \\
\hline Ireland & 6.42 & 7.21 & 6.58 & 3.87 & 9.7 \\
\hline France & 6.5 & 4.67 & 5.51 & 4.96 & 9.6 \\
\hline Germany & 6.31 & 5.55 & 6.12 & 5.88 & 9.62 \\
\hline United Kingdom & 6.18 & 5.62 & 6.13 & 4.57 & 9.61 \\
\hline Italy & 6.07 & 4.6 & 5.07 & 2.62 & 9.54 \\
\hline Spain & 5.98 & 5.39 & 5.16 & 2.5 & 9.47 \\
\hline Greece & 5.43 & 4.82 & 4.32 & 1.96 & 9.36 \\
\hline Portugal & 5.94 & 5.26 & 4.95 & 1.91 & 9.22 \\
\hline Czech Republic & 5.34 & 5.56 & 4.51 & 2.57 & 9.16 \\
\hline Hungary & 6.33 & 5.68 & 4.71 & 2.34 & 8.94 \\
\hline Poland & 5.61 & 4.04 & 3.23 & 1.95 & 8.77 \\
\hline Source: Lin & $2010)$ & & & & \\
\hline
\end{tabular}

Source: Lin and Edvinsson (2010).

phenomenon in nearly 60 per cent. The value of Pearson's R test totals 0.769 , which indicates a (rather strong) positive relationship between the variables. Conclusion: there is a statistically significant relationship between the analyzed variables.

In the case of the H4 hypothesis: There is a correlation between the process capital level for particular country and the corruption level of this country, the determination coefficient $\mathrm{R}^{2}$ totals 0.894 , which means that the presented model describes the analysed phenomenon in nearly 90 per cent. The value of Pearson's R test totals 0.945 , which indicates a strong positive relationship between the variables. Conclusion: there is a statistically significant relationship between the analyzed variables.

In the case of the H5 hypothesis: There is a correlation between the renewal capital level for particular country and the corruption level of this country, the determination coefficient $\mathrm{R}^{2}$ totals 0.806 , which means that the presented model describes the analysed phenomenon in nearly 90 per cent. The value of Pearson's R test totals 0.898 , which indicates a strong positive relationship between the variables. Conclusion: there is a statistically significant relationship between the analyzed variables.

In the case of the H6 hypothesis: There is a correlation between the financial capital level for particular country and the corruption level of this country, the determination coefficient $\mathrm{R}^{2}$ totals 0.566 , which means that the presented model describes the analysed phenomenon in nearly 57 per cent. The value of Pearson's R test totals 0.752 , which 
indicates a positive relationship between the variables. Conclusion: there is a statistically significant relationship between the analyzed variables.

In the case of a $\mathrm{H} 7$ control hypothesis: There is a relationship among GDP per capita along, NIC and CPI.

The following model has been obtained:

$$
y=0.32 x_{1}+0.02 x_{2}-3.69,
$$

where: $y$ - response (dependent) variable - the level of corruption (CPI); $x_{1}$ - responding (independent) variable - GDP per capita; $x_{2}$ - responding (independent) variable the level of intellectual capital.

The determination coefficient $\mathrm{R}^{2}$ totals 0.9169 , which means that the presented model describes the analysed phenomenon in nearly 92 per cent. Such a high result requires the verification: it is necessary to prove that the data are not accidental. The value of the F statistics for two responding variables at 13 degree levels $(d f)$ totals 71.795 , which, when compared with the threshold level $\mathrm{F}^{*}$ of 2.76 means that the created linear regression equation is useful. The linear dependence of this model has been presented in the following Figure 1.

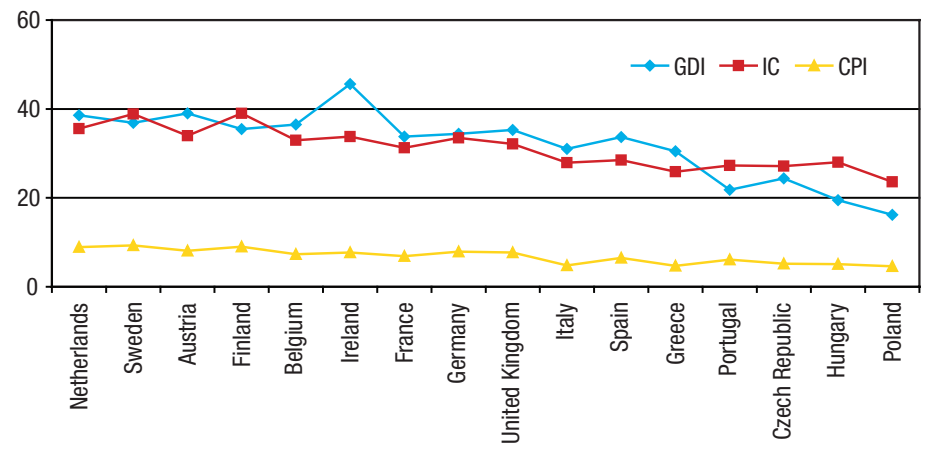

Fig. 1. The dependence between the corruption level of a particular country and its GDP and NIC Source: authors' own study.

Before the verification of the $\mathrm{H} 1$ hypothesis: There is a correlation between the National Intellectual Capital (NIC) level and the level of corruption, was initiated on the basis of the values of National Intellectual Capital established on the basis of the generation method, the value of the coefficient of variation $\left(\mathrm{V}^{*}\right)$ of the examined variables had been verified. In statistics it is assumed that the rejection threshold of a given variable is $\mathrm{V}^{*}=0.2$. Both coefficients of variations obtained have the values which exceed the threshold level of 0.2 and therefore they can be further analysed. In order to verify whether there is any correlation between the level of National Intellectual Capital and the corruption level of a particular country, a linear economic model has been constructed on the basis of the least squares method.

The following model has been obtained:

$$
\begin{gathered}
y=0.12 x+0.97, \\
y=0.34 x-3.8,
\end{gathered}
$$


where: $y$ - response (dependent) variable - the level of corruption (CPI); $x$ - responding (independent) variable - the level of intellectual capital - average IC.

The determination coefficient $\mathrm{R}^{2}$ totals 0.79 , which corresponds to the relation between the corruption level and the intellectual capital level in a given country. In other words, the econometric model presented above explains almost in 80 per cent the analysed phenomenon. At this stage of the analysis let us apply the F statistics in order to find out whether these results are not accidental. On the significance level $\alpha=0.05$ the critical value $\mathrm{F}^{*}$ for one variable at 14 degrees of freedom $(d f)$ totals 4.6 . In the analysed case this value totals 51.29 and it significantly exceeds the critical value $\mathrm{F}^{*}$.

Let us also verify whether there is any linear dependence between the variables when applying Pearson's $\mathrm{R}$ test. The obtained value was $\mathrm{R}=0.886$, which means that there is a relatively strong positive dependence between the analysed phenomena. Conclusion: there is a statistically significant relationship between the analyzed variables. The hypothesis which states that there is linear dependence between the variables can be adopted. In the case of the H8 hypothesis: There is a correlation between the students' IC level for particular country and the corruption level in this country, the determination coefficient $\mathrm{R}^{2}$ totals 0.5195 , which means that the presented model describes the analysed phenomenon in 52 per cent. The value of Pearson's R test totals 0.721 , which indicates that there is linear dependence between the analysed variable; however, it is not high. Therefore there is "average" linear dependence between the analysed variables.

In the case of the H9 hypothesis: There is a correlation between the adults' IC level for particular country and the corruption level in this country, the determination coefficient $\mathrm{R}^{2}$ totals 0.785 , which means that the presented model describes the analysed phenomenon in 78.5 per cent. At this stage of the analysis let us apply the F statistics in order to find out whether these results are not accidental. The value of the F statistics totals 51.26 with the threshold level $\mathrm{F}^{*}$ of 4.6 , which means and the significance level $\alpha=0.05$. Therefore there is linear dependence between the analyzed variables.

In the case of the H10 hypothesis: There is a correlation between the seniors' IC level for particular country and the corruption level in this country, the determination coefficient $\mathrm{R}^{2}$ totals 0.594 , which means that the presented model describes the analysed phenomenon in 59.4 per cent. The value of Pearson's $\mathrm{R}$ test totals 0.886 , which indicates a significant positive relationship between the variables.

The following procedure was adopted for the subsequent detailed hypotheses.

In the case of the $\mathrm{H} 11$ hypothesis: There is a correlation between the adults' HC level for particular country and the corruption level, it was verified whether there is a relationship between the corruption level (CPI) of a given country and the elements of its National Intellectual Capital, i.e. human capital. During the creation of the model twenty-two coefficients were taken into consideration and their values were averaged out. The obtained data have been presented in Table 4.

The following model has been obtained:

$$
y=0.4 x-8.39
$$

where: $y$ - response (dependent) variable - the level of corruption (CPI); $x$ - responding (independent) variable - the level of adults' intellectual capital. 
Table 4. Human, social, structural and relational capital of adults in particular countries

\begin{tabular}{lcccc}
\hline \multicolumn{1}{c}{ Country } & $\begin{array}{c}\text { Adults' } \\
\text { Human Capital }\end{array}$ & $\begin{array}{c}\text { Adults' } \\
\text { Social Capital }\end{array}$ & $\begin{array}{c}\text { Adults' } \\
\text { Structural Capital }\end{array}$ & $\begin{array}{c}\text { Adults' } \\
\text { Relational Capital }\end{array}$ \\
\hline Holland & 40.64 & 34.68 & 191.51 & 2524.7 \\
\hline Sweden & 44.38 & 36.98 & 183.49 & 2835.3 \\
\hline Austria & 40.57 & 28.18 & 196.31 & 3147.1 \\
\hline Finland & 40.98 & 30.27 & 160.08 & 1653.8 \\
\hline Belgium & 39.63 & 28.51 & 180.94 & 690.3 \\
\hline Ireland & 36.86 & 32.03 & 163.59 & 1154.8 \\
\hline France & 40.07 & 23.77 & 180.43 & 18273.8 \\
\hline Germany & 39.55 & 26.13 & 193.41 & 23845.1 \\
\hline United Kingdom & 39.13 & 30.87 & 170.53 & 14715.5 \\
\hline Italy & 31.67 & 29.39 & 159.99 & 20062.0 \\
\hline Spain & 35.92 & 23.07 & 142.78 & 16731.7 \\
\hline Greece & 33.31 & 24.70 & 144.96 & 2182.9 \\
\hline Portugal & 35.42 & 20.69 & 130.09 & 1995.2 \\
\hline Czech Republic & 34.13 & 22.03 & 124.50 & 1510.9 \\
\hline Hungary & 39.20 & 18.80 & 114.00 & 1333.1 \\
\hline Poland & 34.67 & 24.81 & 92.07 & 2231.8 \\
\hline Souce: & & & \\
\hline
\end{tabular}

Source: authors' own study.

The determination coefficient $\mathrm{R}^{2}$ totals 0.7203 , which means that the presented model describes the analysed phenomenon in 72 per cent. When verifying the accidental nature of data selected for the model, we could conclude that since the value of the Snedecor's $\mathrm{F}$ statistics $\mathrm{F}=36.05$ is higher than the threshold value $\mathrm{F}^{*}=4.6$, the data have been appropriately selected. Person's R test was used in order to additionally prove the linearity of the created model. The obtained value $\mathrm{R}=0.849$, which means that there is very high dependence between the analysed phenomena.

In the case of the H12 hypothesis: There is a correlation between the adults' SC level for particular country and the corruption level, it was verified whether there is a relationship between the corruption level (CPI) of a given country and the level of social capital of adults. During the creation of the model seven coefficients were taken into consideration and their values were averaged out. The determination coefficient $\mathrm{R}^{2}$ totals 0.5237 , which means that the presented model describes the analysed phenomenon in 52 per cent. When verifying the accidental nature of data selected for the model, we could conclude that since the value of the Snedecor's F statistics F $=15.4$ is higher than the threshold value $\mathrm{F}^{*}=4.6$, the data have been appropriately selected. When verifying the accidental nature of data selected for the model, we could conclude that since the value of the Snedecor's $F$ statistics $F=15.4$ is higher than the threshold value $F^{*}=4.6$, the data have been appropriately selected. Since the above model does not determine 
the degree of linearity, Pearson's $\mathrm{R}$ test was used. The obtained result, i.e. $\mathrm{R}=0.724$, confirms quite high positive relationship between the level of social capital of adults and the level of corruption in a particular country.

In the case of the H13 hypothesis: There is a correlation between the adults' STRC level for particular country and the corruption level, it was verified whether there is a relationship between the corruption level (CPI) of a given country and the level of structural capital of adults. During the creation of the model twenty eight coefficients were taken into consideration and their values were averaged out. The determination coefficient $\mathrm{R}^{2}$ totals 0.5920 , which means that the presented model describes the analysed phenomenon in nearly 60 per cent. When verifying the accidental nature of data selected for the model, we could conclude that since the value of the Snedecor's F statistics F $=20.3$ is higher than the threshold value $\mathrm{F}^{*}=4.6$, the data have been appropriately selected. Still, a 60 per cent correspondence between the data and the model can be considered unsatisfactory and therefore Pearson's R test was used in order to verify the linear dependence between the variables. The obtained value was $R=0.769$, which means that there is high linear dependence between the level of structural capital of adults and the level of corruption.

In the case of the H14 hypothesis: There is a correlation between the adults' RC level for particular country and the corruption level, it was verified whether there is a relationship between the corruption level (CPI) of a given country and the level of relational capital of adults. During the creation of the model seven coefficients were taken into consideration and their values were averaged out. Since the average relational capital value was high, the value of coefficient of variation $(\mathrm{V})$ for the analysed data was verified before starting any further analysis. The coefficient of variation $\mathrm{V}=1.15$ was higher than the threshold value which allows for further analysis $\left(\mathrm{V}^{*}=0.2\right)$ and therefore the next step was to determine a linear model using the least squares method. The coefficient of determination $\mathrm{R}^{2}$ totals 0.00064 , which means that the created model only describes 0.6 per cent of the cases of the analysed phenomenon. When verifying the accidental nature of the data selected for the model it could be concluded that since the value of the Snedecor's $F$ statistics $F=0.009$ is lower than the threshold value $F^{*}=4.6$, the data have been selected at random.

Pearson's $\mathrm{R}$ test gave the result of $\mathrm{R}=-0.025$, which means that there is practically no dependence between the analysed variables.

In the case of controlled H15 hypothesis: there is a relationship among GDP per capita, NIC (or adults' IC) and CPI level, hypothesis it was verified whether the there is a relationship among corruption level (CPI) of a given country, the National Intellectual Capital (NIC) and the GDP per capita. The determination coefficient $\mathrm{R}^{2}$ totals 0.7888 , which means that the presented model describes the analysed phenomenon in nearly 79 per cent. Such a high result requires the verification in order to prove that the data are not accidental. The value of the $\mathrm{F}$ statistics for two responding variables at 13 degree levels $(d f)$ totals 24.28 , which, when compared with the threshold level $\mathrm{F}^{*}$ of 2.76 , means that the created linear regression equation is useful.

The linear dependence of this model has been presented in Figure 2. 




Fig. 2. The dependence between the level of corruption in a given country and its GDP and NIC Source: authors' own study.

The summaries of research results in tabular format are presented in Table 5 and Table 6.

Table 5. Descriptive statistics

\begin{tabular}{cccccccc}
\hline & $\mathrm{N}$ & Minimum & Maximum & Mean & SE & Standard deviation & Variance \\
\hline NIC & 16 & 23.59 & 39.03 & 31.2063 & 1.13534 & 4.54135 & 20.624 \\
\hline CPI & 16 & 4.6 & 9.3 & 6.863 & 0.4057 & 1.6227 & 2.633 \\
\hline N & 16 & & & & & \\
\hline
\end{tabular}

Source: authors' own study.

Table 6. Results of the tests used in testing hypothesis

\begin{tabular}{ccccccc}
\hline Hypothesis & $\mathrm{N}$ & R-square & R Pearsona & Asympt. SE & Significant level & F-Snedecora \\
\hline 1 & 16 & 0.9151 & 0.957 & 0.013 & 0.000 & \\
\cline { 1 - 5 } 2 & 16 & 0.703 & 0.838 & 0.057 & 0.000 & \\
\cline { 1 - 5 } 3 & 16 & 0.592 & 0.769 & 0.083 & 0.000 & \multirow{2}{*}{150.842} \\
\cline { 1 - 5 } 4 & 16 & 0.894 & 0.945 & 0.020 & 0.000 & \\
\cline { 1 - 5 } 5 & 16 & 0.806 & 0.898 & 0.030 & 0.000 & \\
\hline 6 & 16 & 0.556 & 0.752 & 0.086 & 0.000 &
\end{tabular}

Notes: $\mathrm{Df}=14 ; \mathrm{F}^{*}=4.6$; Significant level for R-square $=0.05$.

Source: authors' own study.

\section{Limitations and future research}

The limitations of this research include the following:

- the comparison between country is limited by the accessibility of available data, which might created a problem in studies of the intellectual capital and the corruption level; 
- the data used for examined National Intellectual Capital and corruption perception can only describe the past situation, than the current situation;

- the value of results within the NICI40 analysis depends on the quality of the raw data from the OECD database and the World Competitiveness Report, and within generational method it relies on the quality of data used for computing 117 indicators;

- measuring corruption across countries is a difficult task and the country coverage differs according to different measures;

- recent research shows that the gap between perception of corruption (CPI) and real corruption can be even larger than expected;

- on the basis of collected data, it is not possible to identify the direction of the relationship (correlation) between a nation's intellectual capital and its corruption level. It is only possible to establish whether a relationship (correlation) between the level of corruption and the level of a nation's intellectual capital exists and how strong it is, without determining the relationship between these variables. The existence of such a relationship cannot be ruled out. Logical reasoning and the discussed results of third-party studies suggest that such a relationship may exist.

The suggestions for future research include the following:

- indicators used for examination each type of National Intellectual Capital can be weighted according to their importance in anti-corruption policies as some of them may have different degrees of importance in corruption prevention;

- the future research examined relationship between the different types of national capital can be useful to provide further insight for developing effective corruption prevention;

- the study should be done every year; this would be particularly important in terms of making it possible to examine the status and trends of the 16 countries, especially the level of National Intellectual Capital for particular generational groups;

- there are many studies on the relationship between national culture and corruption. Hence, further research focused on the relation between national culture and National Intellectual Capital would e us with the clear illustration for the dependence between National Intellectual Capital and corruption;

- it is highly recommended to conduct research on the relationship between National Intellectual Capital and corruption that would use an index different from CPI used for the description of corruption level (e.g. the Control of Corruption index, the International Country Risk Guide or the Incidence of Bribes from the International Crime Victim Surveys);

- determination of the correlation strength between NIC and CPI is the first step in evaluating intellectual capital as a factor which may reduce the scale of corruption. Evidence of a strong relationship between NIC and CPI confirms the author's hypothesis that a strong relationship exists, at the same time proving that further research must be carried out to determine the direction of this relationship. Based on the results of such research (providing that NIC is confirmed to have an effect on CPI), it will be possible to recommend new methods for preventing corruption through the development of NIC. 


\section{Conclusions}

The author's main objective was to examine the relationship between National Intellectual Capital and corruption. The conducted research indicated the significant statistical relation between the level of National Intellectual Capital and the corruption level.

A significant statistical relation between particular types of National Intellectual Capital and corruption was also demonstrated. I am aware that the paper provides more questions (included in the Limitations and future research section) than answers. Determination of the correlation strength between NIC and CPI is the first step in evaluating intellectual capital as a factor which may reduce the scale of corruption. Evidence of a strong relationship between NIC and CPI confirms the author's hypothesis that a strong relationship exists, at the same time proving that further research must be carried out to determine the direction of this relationship. Based on the results of such research (providing that NIC is confirmed to have an effect on CPI), it will be possible to recommend new methods for preventing corruption through the development of NIC. I hope that the present study provides a platform that any country may use to discover its strengths and weaknesses and find the areas on which it should be concentrating as well as to invest in the fight with corruption while aspiring to excellence.

\section{References}

Ades, A.; Di Tella, R. 1995. Competition and Corruption: Draft Paper. Keble College. Oxford: Oxford University.

Ades, A.; Di Tella, R. 1997. National champions and corruption: some unpleasant interventionist arithmetic, The Economic Journal 107: 1023-1042.

http://dx.doi.org/10.1111/j.1468-0297.1997.tb00005.x

Ades, A.; Di Tella, R. 1999. Rents, competition, and corruption, The American Economic Review 89: 982-994. http://dx.doi.org/10.1257/aer.89.4.982

Alt, J. E.; Lassen, D. D. 2002. The Political Economy of Institutions and Corruption in American States: Paper presented at the Danish Public Choice Workshop in Copenhagen, November.

Andriessen, D.; Stam, C. 2004. The Intellectual Capital of the European Union / Measuring the Lisbon Agenda [cited 29 October 2010]. Available from Internet: http://www.intellectualcapital. nl/artikelen/ICofEU 2004.pdf

Aquino, K.; Reed, A. II. 2002. The self-importance of moral identity, Journal of Personality and Social Psychology 83: 1423-1440. http://dx.doi.org/10.1037/0022-3514.83.6.1423

Ashforth, B. E.; Gioia, D. A.; Robinson, S. L.; Trevino, L. K. 2008. Re-viewing organizational corruption, Academy of Management Review 33(3): 670-684.

http://dx.doi.org/10.5465/AMR.2008.32465714

Ashour, A. 2006. Combating Corruption: Systemic and Strategic Perspectives: UNDP POGAR concept paper. Beirut: United Nations Development Programme.

Banaji, M. R.; Bazerman, M. H.; Chugh, D. 2003. How (un)ethical are you?, Harvard Business Review 81(12): 56-64.

Baucus, M. S.; Near, J. P. 1991. Can illegal corporate behavior be predicted? An event history analysis, Academy of Management Journal 34: 9-36. http://dx.doi.org/10.2307/256300

Bjornskov, C. 2003. Corruption and Social Capital, Working Paper 03-13. Department of Economics, Aarhus School of Business. 
Bjornskov, C. 2004. How Does Social Trust Affect Economic Growth, Working Paper 06-02. Department of Economics, Aarhus School of Business.

Bontis, N. 2005. National Intellectual Capital Index: The Benchmarking of Arab Countries, in A. Bounfour, L. Edvinsson. Intellectual Capital for Communities. Boston: Elsevier ButterworthHeinemann. http://dx.doi.org/10.1016/B978-0-7506-7773-8.50011-X

Bontis, N. 2004. National intellectual capital index: a United Nations initiative for the Arab region, Journal of Intellectual Capital 5(1): 13-39. http://dx.doi.org/10.1108/14691930410512905

Brief, A. P.; Buttram, R. T.; Dukerich, J. M. 2001. Collective Corruption in the Corporate World: toward a Process Model, in M. E. Turner (Ed.). Groups at Work: Theory and Research. Mahwah, NJ: Lawrence Erlbaum Associates, 471-499.

Broadman, H. G.; Recanatini, F. 1999. Seeds of Corruption - Do Market Institutions Matter?, World Bank Policy Research Working Paper 2368. Washington, DC.

Callahan, D. 2004. The Cheating Culture: Why More Americans are Doing Wrong to Get Ahead. Orlando, FL: Harcourt.

Cooter, R. D. 2000. Do good laws make good citizens? An economic analysis of internalized norms, Virginia Law Review 86(8): 1577-1601. http://dx.doi.org/10.2307/1073825

Coupet, E. Jr. 2003. Corruption, investment and economic growth: theory and international evidence, Journal of Business and Economics Research 1(1): 93-107.

Drucker, P. F. 1993. Post-Capitalist Society. New York: Harper Collins.

EIS. 2006. European Innovation Scoreboard 2006: Comparative Analysis of Innovation Performance. MERIT [cited 30 November 2010]. Available from Internet: http://www.proinno-europe. eu/doc/EIS2006_final.pdf

EIS. 2007. European Innovation Scoreboard 2006: Comparative Analysis of Innovation Performance. MERIT [cited 30 November 2010]. Available from Internet: http://www.proinno-europe. eu/admin/uploaded_documents/European_Innovation_Scoreboard_2007.pdf

Eisenberg, N. 2000. Emotion, regulation, and moral development, Annual Review of Psychology 51: 665-697. http://dx.doi.org/10.1146/annurev.psych.51.1.665

Elliot, K. A. 1997. Corruption as an International Policy Problem: Overview and Recommendations, in K. A. Elliot (Ed.). Corporation and the Global Economy. Washington: Institute for International Economics, 175-233.

Easterly, W.; Levine, R. 1997. Africa's growth tragedy: policies and ethnic divisions, Quarterly Journal of Economics 112: 1203-1250. http://dx.doi.org/10.1162/003355300555466

EU. 2004. Competitiveness and Benchmarking European Competitiveness. Report 2004, Commission staff working document SEC (2004)1397. Office for Official Publications of the European Communities.

EU. 2005. Effectiveness of ICT RTD Impacts on the EU Innovation System [cited 12 November 2010]. Available from Internet: http://ec.europa.eu/dgs/information_society/evaluation/studies/ s2005_03/index_en/htm

EU. 2006a. Evaluating the Effectiveness of European ICT RTD and Innovation Systems [cited 12 November 2010]. Available from Internet: http://ec.europa.eu/dgs/information_society/evaluation/studies/s2005_03/index_en/htm

EU. 2006b. Effectiveness of IST RTD Impacts on the EU Innovation System. Annexes to the Final Report [cited 13 November 2010]. Available from Internet: http://ec.europa.eu/dgs/information_society/evaluation/studies/s2005_03/index_en/htm

Fukuyama, F. 1995. Trust: The Social Virtue and the Creation of Prosperity. London: Harnish Hamilton. 
Fukuyama, F. 1999. Social Capital and Civil Society: paper presented at the IMF Conference on Second Generation Reforms, November 8-9. Washington: IMF Institute and the Fiscal Affairs Department.

Gerring, J.; Thacker, S. 2005. Do neoliberal policies deter political corruption?, International Organization 59: 233-254. http://dx.doi.org/10.1017/S0020818305050083

Getz, K.; Volkema, J. 2001. Culture, perceived corruption, and economies, Business and Society 40(1): 7-30. http://dx.doi.org/10.1177/000765030104000103

Goel, R. K.; Nelson, M. A. 2005. Economic freedom versus political freedom: cross-country influences on corruption, Australian Economic Papers 44: 121-133.

http://dx.doi.org/10.1111/j.1467-8454.2005.00253.x

Goldsmith, A. A. 1999. Slapping the grasping hand: correlates of political corruption in emerging markets, The American Journal of Economics and Sociology 58(4): 866-883.

Gupta, S.; Davoodi, H.; Tiongson, E. R. 2001. Corruption and the Provision of Health Care and Education Services, in A. K. Jain (Ed.). The Political Economy of Corruption. London: Routledge, 111-141.

Harris, D. 2007. Bonding Social Capital and Corruption: A Cross-National Empirical Analysis. Environmental Economy and Policy Research, Working Papers No 27.2007. University of Cambridge.

Henderson, D. R. 1999. Power corrupts - editorial comment, The Wall Street Journal. April 19. Herzfeld, T.; Weiss, C. 2003. Corruption and legal (in)effectiveness: an empirical investigation, European Journal of Political Economy 19: 621-632.

http://dx.doi.org/10.1016/S0176-2680(03)00018-1

KAM. 2007. Knowledge Assessment Methodology. KAM: World Bank.

Lambsdorff, G. J. 1999. Corruption in empirical research - a review, Working Paper. Göttingen: Transparency International.

Lambsdorff, G. J. 2007. The Institutional Economics of Corruption and Reform: Theory, Evidence and Policy. Cambridge: Cambridge University Press.

http://dx.doi.org/10.1017/CBO9780511492617

Lancaster, T.; Montinola, G. 1997. Toward a methodology for the comparative study of political corruption, Criminal Law and Social Change 27: 185-206.

http://dx.doi.org/10.1023/A:1008274416350

Lapalombara, J. 1994. Structural and institutional aspects of corruption, Social Research 61: $325-350$.

Lin, C. Y. Y.; Edvinsson, L. 2010. What National Intellectual Capital indices can tell about the global economic crisis of 2007-2009?, Electronic Journal of Knowledge Management 8(2): 253-266.

Lin, C. Y. Y.; Lin, T. Y. 2008. National Intellectual Capital: exploring Taiwan's standing, International Journal of Learning and Intellectual Capital 5(3/4): 311-331.

http://dx.doi.org/10.1504/IJLIC.2008.021014

Malhotra, Y. 2000. Knowledge assets in the global economy: assessment of National Intellectual Capital, Journal of Global Information Management 8(3): 5-15.

http://dx.doi.org/10.4018/jgim.2000070101

Malhotra, Y. 2003. Managing and Measuring Knowledge Assets in the Public Sector, Working Paper. Syracuse University.

Marcus, B.; Schuler, H. 2004. Antecedents of counterproductive behaviour at work: a general perspective, Journal of Applied Psychology 89: 647-660.

http://dx.doi.org/10.1037/0021-9010.89.4.647 
Moily, M. V. 2009. National Seminar on Fighting Crime related to Corruption [cited 10 November 2010]. Available from Internet: http://www.pib.nic.in/release/release.asp?relid=52596

OECD. 2000. International Science and Technology Co-Operation: towards Sustainable Development, in Proc. of the OECD Seoul Conference, Paris.

OECD. 2006. Intellectual Assets and Value Creation: Implications For Corporate Reporting [cited 12 November 2010]. Available from Internet: http:/www.oecd.org/dataoecd/2/40/37811196.pdf

Paldam, M. 2002. The big pattern of corruption. Economics, culture and the Seesaw dynamics, European Journal of Political Economy 18: 215-240.

http://dx.doi.org/10.1016/S0176-2680(02)00078-2

Pasher, E. 1999. The Intellectual Capital of State of Israel. Herzlia Pituach: Kal Press.

Pinto, J.; Leana, C. R.; Pil, F. K. 2008. Corrupt organizations or corrupt individuals? Two types of organization-level corruption, Academy of Management Review 33(3): 685-708.

http://dx.doi.org/10.5465/AMR.2008.32465726

Punch, M. 2003. Rotten orchards: pestilence, police misconduct and system failure, Policing and Society 13: 171-196.

Putnam, R. D. 2000. Bowling Alone: The Collapse and Revival of American Community. New York: Simon \& Schuster.

Rembe, A. 1999. Invest in Sweden: Report 1999. Stockholm: Halls Offset AB.

Reynolds, S. J. 2006. Moral awareness and ethical predispositions: investigating the role of individual differences in the recognition of moral issues, Journal of Applied Psychology 91: 223-243. http://dx.doi.org/10.1037/0021-9010.91.1.233

Rijckeghem, van C; Weder, B. 2001. Bureaucratic corruption and the rate of temptation: do wages in the civil service affect corruption, and by how much?, Journal of Development Economics 65(2): 307-331.

Seleim, A.; Bontis, N. 2009. The relationship between culture and corruption: a cross-national study, Journal of Intellectual Capital 10(1): 165-184. http://dx.doi.org/10.1108/14691930910922978

Shkolnikov, A.; Wilson, A. 2005. Dispelling Corruption Myths: What Works and What Doesn't, ECONOMIC REFORM Feature Service [cited 17 November 2010]. Available from Internet: http://www.cipe.org/pdf/publications/fs/060805.pdf

Spring Project. 2002. [cited 17 November 2010]. Available from Internet: http://cordis.europa.eu/ data/PROJ_FP5/ACTIONeqDndSESSIONeq2172200595ndDOCeq104ndTBLeqEN_PROJ.htm

Ståhle, P. 2008. National Intellectual Capital as an Economic Driver: Perspectives on Identification and Measurement, in G. Ahonen (Ed.). Inspired by Knowledge in Organizations. Essays in honour of Professor Karl-Erik Sveiby in his 60th birthday 29th June 2008. Swedish School of Economics and Business Administration.

Sung, H. E. 2002. A convergence approach to the analysis of political corruption: a cross-national study, Crime, Law and Social Change 38(2): 137-160. http://dx.doi.org/10.1023/A:1020239413622 Svendsen, G. 2003. Social capital, corruption and economic growth: Eastern and Western Europe, Working Paper 03-21. University of Aarhus [cited 12 November 2010]. Available from Internet: http://www.hha.dk/nat/wper/03-21_gts.pdf

Svensson, J. 2005. Eight questions about corruption, Journal of Economic Perspectives 19: 19-42. http://dx.doi.org/10.1257/089533005774357860

The Board of Strategic Advisers to the Prime Minister of Poland. 2008. The Report on Intellectual Capital of Poland [cited 30 October 2010]. Available from Internet: http://pliki.innowacyjnosc.gpw.pl/Kapital_Intelektualny_Polski.pdf 
Transparency International. 2008. Corruption Perception Index 2008 [cited 26 November 2010]. Available from Internet: http://www.transparency.org/policy_research/surveys_indices/cpi/2008/ cpi_2008_table

Trevino, L. K. 1986. Ethical decision making in organization: a person-situation interactionist model, Academy of Management Review 11: 601-617.

UNPAN. 2003. Expanding Public Space for the Development of the Knowledge Society, in Report of the Ad Hoc Expert Group Meeting on Knowledge Systems for Development 4-5 September 2003, NY [cited 17 November 2010]. Available from Internet: http://www.unpan.org

Urra, F. J. 2007. An Analytical Review of Corruption Measurement and Its Problems: Perception, Error and Utility. Georgetown University: Edmund A. Walsh School of Foreign Service. Available from Internet: http://unpan1.un.org/intradoc/groups/public/documents/apcity/unpan028792.pdf World Bank. 1997. World Development Report. Oxford: Oxford University Press.

World Bank. 1998. World Development Report: Knowledge for Development. Oxford: Oxford University Press.

World Bank. 2002. The Knowledge Assessment. Methodology and Scoreboard [cited 10 November 2010]. Available from Internet: http://www1.worldbank.org

Zhao, J. H.; Kim, S. H.; Du, J. 2003. The impact of corruption and transparency on foreign direct investment: an empirical analysis, Management International Review 43: 41-62.

Agata STACHOWICZ-STANUSCH (PhD, DSc) is an Associate Professor of Management at the Silesian University of Technology in Poland. She is the Head of the Management and Marketing Department. Stachowicz-Stanusch has authored and edited ten books, including co-authoring Contemporary Management: Collaborating in a Networked World which will be published in 2012 by Palgrave Macmillan, Organizational Immunity to Corruption: Building Theoretical and Research Foundations (IAP 2010), and was co-author and co-editor, together with Charles Wankel, of three books: Education for Integrity: Ethically Educating Tomorrow's Business Leaders (Emerald 2011), Effectively Integrating Ethical Dimensions into Business Education (IAP 2011), and Handbook of Research on Teaching Ethics in Business and Management Education (IGI Global 2011). She is also the author of over seventy research papers in domestic and international journals and conference proceedings. She is a reviewer of Academy of Management (AOM) and European Academy of Management (EURAM) as well as the Journal of Brand Management (Palgrave MacMillan) and Journal of Organizational Change Management (Emerald). Stachowicz-Stanusch is a member of Polish Academy of Sciences, the Committee on Organizational and Management Sciences, Katowice Department, and PRME Working Group on Anti-Corruption. She is also a co-founder of the Organizational and Management Journal edited by the Silesian University of Technology as well as a member of the Editorial Board of the Global Management Journal. 